\title{
Intracaldera explosions and lava emissions during the 2007 caldera collapse of Piton de la Fournaise, La Réunion Island
}

\author{
Daniele Vergani ${ }^{1,2} \cdot$ Jocelyn McPhie ${ }^{1}$ (D) $\cdot$ Rebecca Carey $^{1} \cdot$ Andrea Di Muro $^{3,4}$
}

Received: 6 September 2021 / Accepted: 6 January 2022 / Published online: 4 February 2022

(c) The Author(s) 2022

\begin{abstract}
The March-April 2007 Piton de la Fournaise basaltic eruption was the most significant eruption on La Réunion Island in historical times. On 2 April, a fissure opened on the southeastern flank of the volcano. Vigorous fountains fed lavas that rapidly reached the coast. Three days later, on the 5-6 April, major caldera collapse occurred at the summit, affecting the floor and walls of Dolomieu caldera. Monitoring records, primarily webcam images, have been analysed and integrated with geophysical data to reconstruct the chronology of events at the summit during caldera collapse. Those events included progressive subsidence of the former caldera floor, landslides, explosions, lava emissions and steam fumaroles, and lasted until 19 April though diminished greatly in frequency after 7 April. For two days after the main caldera collapse on 5 April, subsidence increments, intracaldera lava emission and explosions were closely associated in time and in location. Abundant steam and wet talus on the caldera walls imply that the shallow hydrothermal system and/or groundwater were exposed by subsidence. The presence of juvenile components in ash deposited at the summit during caldera collapse and the close link between intracaldera lavas and explosions suggest that many explosions were phreatomagmatic. Although caldera collapse was related to magma withdrawal from beneath the summit via the flank vent activity, numerous intracaldera lava emissions indicated that magma was nevertheless present at the summit during caldera collapse. We infer that the lava emissions were fed by an intrusion emplaced at the end of March into the eastern summit region and that the intrusion was being actively recharged during caldera collapse. Caldera collapse involved a complex combination of magma withdrawal and magma replenishment at separate summit reservoirs.
\end{abstract}

Keywords Piton de la Fournaise $\cdot$ Caldera collapse $\cdot$ Intracaldera lava $\cdot$ Phreatomagmatic explosion $\cdot$ Landslide $\cdot$ Magma withdrawal

Editorial responsibility: J. Eychenne

Jocelyn McPhie

j.mcphie@utas.edu.au

1 School of Natural Sciences, University of Tasmania, Hobart, TAS, Australia

2 Pitt\&Sherry, PO Box 94, Hobart, TAS 7001, Australia

3 Université de Paris, Institut de Physique du Globe de Paris, CNRS, F-75005 Paris, France

4 Observatoire Volcanologique du Piton de la Fournaise, Institut de Physique du Globe de Paris, F-97418 La Plaine des Cafres, France

\section{Introduction}

Collapse events at summit calderas on large basaltic volcanoes are known to be linked to magma withdrawal by means of flank eruptions although there are only a small number of well documented examples of the connection: the caldera-forming events at Fernandina volcano (1968) in the Galapagos Archipelago (Ecuador; Simkin and Howard 1970), Miyakejima volcano (2000; Geshi et al. 2002; Geshi and Oikawa 2008) in Japan, Piton de la Fournaise on La Réunion Island (2007; Michon et al. 2007) and Kilauea in the USA (2018; Neal et al. 2019). These caldera collapses are also similar in that they displayed (i) step-like collapse processes, (ii) cyclic deformation and seismicity, and (iii) small explosive eruptions at the summit. At Fernandina and Miyakejima, the explosions were magmatic and/or phreatomagmatic, indicating the presence of magma at the summit 
caldera despite magma withdrawal clearly having taken place. This paradox was even more conspicuous during the 2007 Piton de la Fournaise caldera collapse because this collapse also involved multiple intracaldera emissions of lavas (Staudacher et al. 2009).

The caldera collapse in 2007 on Piton de la Fournaise was the most significant collapse to occur at the volcano in the last 300 years (Michon et al. 2007). The collapse and related events were observed and recorded in detail by the Observatoire Volcanologique du Piton de la Fournaise/Institut de Physique du Globe de Paris (OVPF/IPGP) using multiple monitoring techniques including seismic and deformation networks, and three webcams (Staudacher et al. 2009). Although a high level of understanding and consensus exists regarding the 2007 eruption and collapse processes (e.g., Michon et al. 2007; 2009; Urai et al. 2007; Peltier et al. 2009b; Staudacher et al. 2009; Fontaine et al. 2014; 2019; Duputel et al. 2019), a detailed correlation among seismicity, deformation (inflation versus deflation), collapse and related intracaldera activity has not previously been attempted. Our analysis of monitoring imagery also discriminates among different types of collapse-related intracaldera activity (lava emissions, explosions, landslides). This correlation exercise has generated a chronology of events which in turn, provides a foundation for investigating the evolution of caldera collapse and the connections between the collapse increments and related activity. In addition, we describe and interpret proximal ash deposits that were emplaced at the summit and are now largely eroded. Because the timing of events has been carefully constrained, the proximal ash deposits can be linked to observed eruptive or other events. They provide indirect information on the role of magma and the summit hydrothermal system and/or ground water in explosive activity that accompanied collapse. The results collectively support the interpretation that the intracaldera lava emissions were products of rupturing of a still molten intrusion emplaced a week or so before caldera collapse and undergoing active recharge. This explanation of the intracaldera lava emissions implies magma was present at the summit even though magma withdrawal from beneath the summit was the main driver of caldera collapse.

\section{Geological setting: Piton de la Fournaise}

La Réunion Island is a basaltic volcanic island located in the southwestern Indian Ocean (Fig. 1a). The island is the emergent part of a volcanic edifice built on oceanic crust at $\sim 4000 \mathrm{~m}$ below sea level (Gallart et al. 1999). The island comprises two main volcanic edifices: Piton des Neiges (northwest) and Piton de la Fournaise (southeast), both of which have a shield volcano morphology
(Fig. 1b). Piton de la Fournaise reaches $2632 \mathrm{~m}$ above sea level (asl) and the base is $\sim 30 \mathrm{~km}$ in diameter. Eruptions started about 530,000 years ago (Gillot and Nativel 1989) and have been dominantly effusive, producing ' $a$ ' $\bar{a}$ and pāhoehoe lavas, and weakly explosive, involving hawaiian and strombolian styles (e.g., Michon et al. 2013; Ort et al. 2016; Roult et al. 2012; Thivet et al. 2020).

The morphology of Piton de la Fournaise is dominated by three, almost concentric horseshoe-shaped depressions open to the east and created by three different collapse events (Gillot et al. 1994; Michon et al. 2016). The youngest, Enclos Fouqué (4.5 ka), encloses the current active edifice of Piton de la Fournaise volcano, the Central Cone (Fig. 1b). The Central Cone has a basal diameter of $\sim 3 \mathrm{~km}$ and height of $400 \mathrm{~m}$. Dolomieu caldera occurs at the summit of the Central Cone. The caldera is elongate east-west $(1.1 \mathrm{~km} \times 0.8 \mathrm{~km})$ and $\sim 330 \mathrm{~m}$ deep. Bory crater occurs on the western rim of Dolomieu caldera. The diameter of Bory crater is $\sim 200 \mathrm{~m}$ and it is $\sim 20 \mathrm{~m}$ deep (Fig. 1c). From 1966 until 2007, the floor of Dolomieu caldera was flat, being underlain by lavas erupted from intracaldera vents on multiple occasions (Derrien et al. 2015). Dolomieu caldera has undergone numerous collapse events in the last hundred years (Peltier et al. 2012; Michon et al. 2013; Derrien et al. 2015). The pre-2007 Dolomieu caldera inherited ring faults close to the inner rim from previous collapse events (Michon et al. 2009).

The shallow magma reservoir of Piton de la Fournaise is inferred to lie below the Central Cone between $2.5 \mathrm{~km}$ below sea level and close to sea level, as suggested by geophysical (Nercessian et al. 1996; Peltier et al. 2009a; Prôno et al. 2009) and geochemical data (Di Muro et al. 2014; 2016). Based on deformation and seismic records analysed by Peltier et al. (2009b), Massin et al. (2011) and Fontaine et al. (2014), the shallow reservoir was recharged during January to early March 2007, just before the April 2007 eruption. The shallowest plumbing system below the Dolomieu caldera is located between sea level and the surface (i.e. between sea level and $2.6 \mathrm{~km}$ asl) and is characterised by small and transient intrusions, dykes and sills in an intensely fractured zone (Peltier et al. 2009a; Lénat et al. 2012a, b; Lénat 2016; Di Muro et al. 2014; Michon et al. 2016).

Prior to the 2007 eruption, a hydrothermal system was inferred to exist beneath the Central Cone, extending to a few hundred metres below the surface (Lénat et al. 2012a, b). This inference proved to be correct because the 2007 caldera collapse exposed hydrothermally altered caldera walls, and numerous intracaldera steam fumaroles, thermal anomalies and areas of wet talus were observed (this study; Urai et al. 2007; Staudacher 2010; Lénat et al. 2012a; Michon et al. 2013; Mauri et al. 2018). 
Fig. 1 a Location of La Réunion Island (red star) in relation to Africa. b Digital elevation model of Piton de la Fournaise which forms the southeastern part of La Réunion Island. Red square, Piton Basaltes webcam; red triangle, Piton Partage webcam; red circle, Bory webcam. Black cross, Puy MiCote; green cross, Cratère Von Drasche; white cross, Cratère Faujas. White triangle, Piton Tremblet vent. c Aerial view of Piton de la Fournaise summit in December 2006. The floor of Dolomieu caldera is almost flat and 0-100 m below the caldera rim. Red dot, Bory webcam. d Aerial view of the Piton de la Fournaise summit in July 2007, after caldera collapse (b, $\mathbf{c}, \mathbf{d}$ from the OVPF database). The caldera is $800 \mathrm{~m}$ wide, $1100 \mathrm{~m}$ long and the deepest point is $\sim 330 \mathrm{~m}$ below the rim
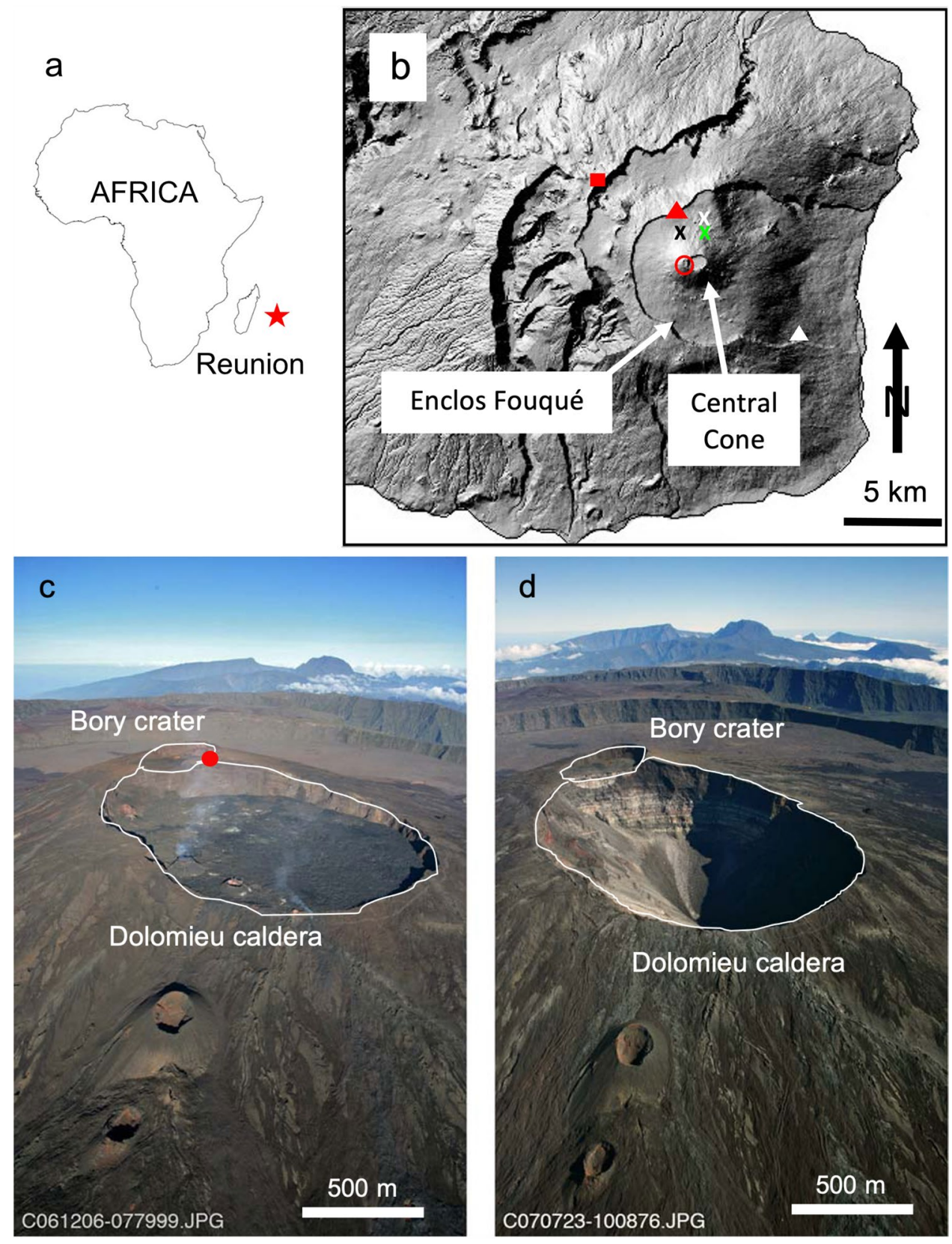

\section{The 2007 eruptions and caldera collapse at Piton de la Fournaise}

In 2007, three eruptions occurred, the first in February, the second in March and the third, and largest, in April-May. The first eruption began at 14:38 GMT on 18 February and involved opening of an east-west-striking fissure on the floor of the Dolomieu caldera. During this event, aphyric basaltic lava spread over almost all the Dolomieu caldera floor and a small portion extended outside the caldera where the fissure intersected the eastern rim (Staudacher et al. 2009; 2016; Di Muro et al. 2014). Starting mid-January 2007, GPS data showed continuous inflation of the summit in an area within $1 \mathrm{~km}$ radius of the centre of Dolomieu caldera, followed by strong inflation comprising horizontal displacement up to $0.1 \mathrm{~m}$ in $\sim 8 \mathrm{~h}$ and vertical displacement up to $0.03 \mathrm{~m}$ in $\sim 12 \mathrm{~h}$ (Peltier et al. 2009b). This strong inflation has been linked to the dyke emplacement that fed 18 February eruption (Fontaine et al. 2014; Peltier et al. 2009b). The eruption was immediately preceded by a 27 -min-long seismic crisis centred beneath the summit (Fontaine et al. 2014). The eruption ended at 05:15 GMT on 19 February, having produced $<1 \times 10^{6} \mathrm{~m}^{3}$ of lava (Staudacher et al. 2009).

After the February eruption, inflation persisted and seismicity increased, which together were taken to indicate continued magma recharge in the shallow reservoir (Peltier et al. 2009a, b; 
Staudacher et al. 2009; Fontaine et al. 2014; Froger et al. 2016). Displacement data from Froger et al. (2016) indicated an area of inflation on the eastern side of the summit extending $4 \mathrm{~km}$ north-south. On the 30 March, a fissure opened at the southern end of the inflated area at $1900 \mathrm{~m}$ asl on the east-southeast flank of the volcano and erupted aphyric basalt (Staudacher et al. 2009; 2016; Di Muro et al. 2014). Before the eruption started, a seismic crisis lasting 145 min was recorded by the broadband seismic station on the northern flank of Piton de la Fournaise and the GPS network registered inflation followed by contraction and displacement toward the southeast and on the northern flank (Peltier et al. 2009b). Together, these data indicated intrusion of magma under the eastern flank (Michon et al. 2007; Peltier et al. 2009b; Staudacher et al. 2009; 2016; Fontaine et al. 2014). This eruption ceased at 05:00 GMT on 31 March after $10 \mathrm{~h}$ (Michon et al. 2007). Thereafter, summit seismicity continued, together with ongoing edifice deflation (Michon et al. 2007; 2009; Staudacher et al. 2009; 2016; Fontaine et al. 2014).

On 2 April, a fissure opened at Piton Tremblet on the southeastern flank of the volcano at about $600 \mathrm{~m}$ asl (Fig. 1b); lava fountains 100 to $150 \mathrm{~m}$ high fed lava flows (Staudacher et al. 2009). The initial magma output rate suggested by analysis of seismic records was very high (up to $600 \mathrm{~m}^{3} \mathrm{~s}^{-1}$; Duputel and Rivera 2019). Seismicity continued to increase and culminated on 5 April with a 4.8 magnitude earthquake (20:48 GMT) that had a hypocenter below the Dolomieu caldera (Fontaine et al. 2014). The earthquake was contemporaneous with sudden inflation and a further significant increase in seismicity (Michon et al. 2007; Peltier et al. 2009b; Staudacher et al. 2009). This inflation and seismicity were associated with the first collapse event, which affected the northwestern sector of the Dolomieu caldera (Michon et al. 2007). Following the first collapse, lava fountain heights at Piton Tremblet reached $>200 \mathrm{~m}$ and the estimated discharge rate was $>200$ $\mathrm{m}^{3} \mathrm{~s}^{-1}$ (Michon et al. 2007; Staudacher et al. 2009). Subsequently, the seismic signal became cyclic, involving increases and decreases in seismicity coeval with deflation and inflation, respectively, over cycle periods lasting between $2 \mathrm{~h}$ and 30 min (Michon et al. 2011). Thirty-eight collapse events were distinguished from precise GPS data in the period between 5 April at 20:48 GMT and 7 April at 00:40 GMT (Michon et al. 2009). The first 16 collapses followed pre-existing summit ring faults and produced most of the final caldera shape
(Michon et al. 2009; Derrien et al. 2020). The final caldera was slightly larger than the former Dolomieu caldera and had a maximum depth of $330 \mathrm{~m}$ (Staudacher et al. 2009) (Fig. 1d). The eruptive activity at Piton Tremblet continued until 1 May, by which time $\sim 130 \times 10^{6} \mathrm{~m}^{3}$ of lava had been erupted in 30 days (Staudacher et al. 2009).

\section{Methods}

The chronology of the 2007 PdF caldera collapse events during the period 5-23 April was constructed by reviewing data recorded by the OVPF webcam monitoring network and available pictures from the OVPF database. Images were reviewed from three webcams located at (i) Bory, on the volcano summit, (ii) Piton Partage, $3 \mathrm{~km}$ NNW of the summit on the edge of Enclos Fouque cliff, and (iii) Piton Basaltes, $7 \mathrm{~km} \mathrm{NW}$ of the summit (Fig. 1b; Table 1). These webcams gave the best coverage of the summit activity. The images from Bory webcam which was nearest to the caldera (Fig. 1b, c) were the most informative; however, any events on the western wall and floor of the caldera were not fully visible.

The webcams were Trendnet TV-IP100 cameras incorporating a CMOS colour sensor and an F:1.8 f:6.0 mm integrated lens, operating at $2.5 \mathrm{~lx}$ lighting minimum with automatic gain control, exposure and white balance. The resolution was $640 \times 480$ pixels and the camera frame rate varied from 1 frame/minute to 1 frame/10 s.

For each day, the time, location, type of activity, and plume colour and plume maximum height were recorded (Supplementary Table S1). Dimensions were calibrated using identifiable markers in the landscape. Altitudes of markers were determined from published altitude data and topographic maps provided by the OVPF (2008 Digital Elevation Model; Institut Geographic National). Markers were clearly visible, being $>100 \mathrm{~m}$ in size, and occupying $>10 \%$ of the view. Markers included (Fig. 1b):

- The highest point on the Central Cone

- Cratère Von Drasche and Cratère Faujas on northern flank of Piton de la Fournaise

- Puy Mi-Cote on the northwestern flank of Piton de la Fournaise
Table 1 Location of OVPF webcams used in this study and image details

\begin{tabular}{llllll}
\hline Webcam & Latitude & Longitude & $\begin{array}{l}\text { Distance } \\
\text { to } \\
\text { Dolomieu } \\
\text { caldera } \\
(\mathrm{km})\end{array}$ & $\begin{array}{l}\text { Horizontal/vertical } \\
\text { angle to the target }\end{array}$ & $\begin{array}{l}\text { Image dimensions: } \\
\text { height x width }(\mathrm{m})\end{array}$ \\
\hline Piton Partage & $21^{\circ} 13^{\prime} 10.01^{\prime \prime} \mathrm{S}$ & $55^{\circ} 42^{\prime} 8.52^{\prime \prime} \mathrm{E}$ & 3 & $152.6^{\circ} / 0^{\circ}$ & $1000 \times 1200$ \\
Piton Basaltes & $21^{\circ} 12^{\prime} 47.46^{\prime \prime} \mathrm{S}$ & $55^{\circ} 39^{\prime} 15.00^{\prime \prime} \mathrm{E}$ & 7 & $119.7^{\circ} / 0^{\circ}$ & $1500 \times 2000$ \\
Bory & $21^{\circ} 14^{\prime} 35.45^{\prime \prime} \mathrm{S}$ & $55^{\circ} 42^{\prime} 32.84 " \mathrm{E}$ & 0.5 & $124^{\circ} / 0^{\circ}$ & $400 \times 600$ \\
\hline
\end{tabular}


- The eastern floor of Dolomieu caldera

- The December 2006 tephra cone inside Dolomieu caldera (before caldera collapse)

- The southern rim and relief of Enclos Fouqué.

The geolocation accuracy was $\pm 1 \mathrm{~m}$ for the closest view (Bory webcam) and $\pm 15 \mathrm{~m}$ for the farthest view (Piton Basaltes webcam).

Another record of summit activity is available in proximal ash deposits from plumes generated during caldera collapse. These deposits were preserved locally in Bory crater where they were sampled in 2009 by the first author. Four sections in Bory crater were logged and all four sections comprise five beds (Vergani 2018). The ash was mostly unconsolidated; however, two beds were locally weakly consolidated and remained intact when removed from the section. The weakly consolidated samples were positioned in plastic containers and then fully impregnated with well mixed, slightly warm resin to preserve the internal structures and avoid bubble formation. Once hardened, the resin blocks were cut with a circular saw for thin-section production. Thin sections were polished on both sides with extreme care to avoid any damage. The unconsolidated ash samples were split into sample sizes of approximately $5 \mathrm{~g}$. The samples were split in two steps using a small particle splitter to ensure a random and representative splitting process. The sub-samples were smeared on glass slides and examined with a binocular microscope.

Grain size, component types and component proportions of each layer were estimated visually for samples of each bed in these ash deposits. Grain size terms follow White and Houghton (2006). Visual estimates of component proportions were determined by comparing the components visible in the field of view of the microscope with quantified percentage images in Terry and Chilingar (1955). The accuracy of the visual estimates is in the order of $\pm 5 \%$. None of the intracaldera lavas or other deposits are accessible.

\section{Results}

In this section, we present the chronology of caldera collapse based on observation of the OVPF webcam records. This chronology has been integrated with published seismic and deformation data. The webcam records show that caldera collapse was accompanied by intracaldera landslides, lava emissions, explosions and fumaroles. Collapse events and explosions can be correlated with seismic data for 6 April which show a distinctive cyclic pattern. Analysis of the proximal ash deposits at the summit provides further information on the nature of the intracaldera explosions.

\section{Timing of caldera collapse events}

Caldera collapse involved multiple increments, the largest of which occurred in a 36-h period starting at 20:48:30 GMT on 5 April (Staudacher et al. 2016), followed by smaller increments during the next 14 days (Table 2; Supplementary Table S1; Derrien et al. 2020). The main collapse events recognised in this study are the same as those of Staudacher et al. (2009) and Michon et al. (2007). We also include collapse events on 12 and 17 April not considered by Staudacher et al. (2009) and Michon et al. (2007) (Fig. 2; Table 2; Supplementary Table S1), consistent with the photogrammetric study of Derrien et al. (2020). Derrien et al. (2020) showed that caldera subsidence lasted longer than previously thought, until 19 April, but decelerated significantly after 7 April. Our data show that the first caldera collapse event on 5 April affected most of the northwestern Dolomieu caldera floor, leaving ledges and terraces along the northeastern, eastern and southern caldera rim (Fig. 2a). On 6 April, the northeastern and eastern ledges collapsed further (Fig. 2b). These ledges partly subsided again on 7 April, together with portions of the southern ledge (Fig. 2c). Events on the 12 and 17 April affected the northeastern (Fig. 2d) and northern (Fig. 2e) caldera rim, respectively. The number of daily collapse events decreased through time and only sporadic collapse events occurred after 10 April, notably on 12 April and 17 April, both of which followed relatively stable periods.

\section{Activity associated with caldera collapse events}

In addition to subsidence, the 2007 caldera collapse events were associated with (1) landslides involving the caldera rim and remnants of the Dolomieu caldera floor, (2) intracaldera lava emissions, and (3) ash and dust plumes from explosions and landslides.

\section{Landslides}

Landslides affected the Dolomieu caldera rim, caldera walls, remnants of the caldera floor and the unconsolidated intracaldera talus (Fig. 3). Landslides were observed during the entire caldera collapse period but decreased in frequency from 20 landslides in $20 \mathrm{~min}$ to one landslide in $20 \mathrm{~min}$. However, the rim of the caldera remained highly unstable for years after the caldera collapse and rockfalls persisted until at least 2011 (Hibert et al. 2017; Derrien et al. 2019).

\section{Lava emissions}

During 6 and 7 April, after the major caldera collapse of 5 April, multiple intracaldera lava emissions were observed. Lava emission was quasi-continuous during this period. 
Table 2 Intracaldera events (collapse increments, landslides, explosions, lava emissions) recorded by three OVPF webcams and photos in the OVPF database. Areas of Dolomieu caldera affected shown in bold font were the main areas affected. All dates relate to April 2007.
0 , no events observed in available images; blank entry, images not reviewed. The times and nature of each event are given in Supplementary Table S1

\begin{tabular}{|c|c|c|c|c|c|c|c|c|}
\hline \multirow{2}{*}{$\begin{array}{l}\text { Webcam } \\
\text { Date }\end{array}$} & \multicolumn{2}{|c|}{ Basaltes ( 7 km NW) } & \multicolumn{2}{|c|}{ Bory $(\sim 0.5 \mathrm{~km} \mathrm{~W})$} & \multicolumn{2}{|c|}{ Partage ( $3 \mathrm{~km} \mathrm{NNW)}$} & \multicolumn{2}{|c|}{$\begin{array}{l}\text { Images from the } \\
\text { OVPF database }\end{array}$} \\
\hline & Events & Area of Dolomieu crater affected & Events & Area of Dolomieu crater affected & Events & $\begin{array}{l}\text { Area of Dolo- } \\
\text { mieu crater } \\
\text { affected }\end{array}$ & Events & $\begin{array}{l}\text { Area of } \\
\text { Dolo- } \\
\text { mieu } \\
\text { crater } \\
\text { affected }\end{array}$ \\
\hline 5 & & & 7 & NW & & & & \\
\hline 6 & 1736 & N-NE, E, E-SE, SE-S, S & 271 & N-NE, E, E-SE, SE-S, S & 63 & E-NE, E & & \\
\hline 7 & 921 & N-NE, NE, E, E-SE, SE, SW, W & 804 & N-NE, NE, E, E-SE, SE, SW, W & & & & \\
\hline 8 & & & & & & & 6 & $\begin{array}{c}\text { N, N-NE, } \\
\text { E-NE, } \\
\text { E-SE }\end{array}$ \\
\hline 9 & & & & & 12 & $\mathrm{~N}, \mathrm{E}$ & & \\
\hline 10 & & & 4 & S, SW, S-SE & & & 2 & E-NE \\
\hline 11 & 0 & & 0 & & & & & \\
\hline 12 & 38 & $\begin{array}{l}\text { E-NE, N, NE, E, E-SE, S, SW, } \\
\text { W }\end{array}$ & 31 & $\begin{array}{l}\text { E-NE, N, NE, E, E-SE, S, SW, } \\
\text { W }\end{array}$ & 2 & E, NE & & \\
\hline 13 & 0 & & 1 & N-NW & 0 & & & \\
\hline 14 & & & & & & & & \\
\hline 15 & 0 & & & & & & & \\
\hline 16 & 0 & & & & 0 & & & \\
\hline 17 & 0 & & 0 & & 0 & & 2 & $\mathrm{~N}$ \\
\hline 18 & 0 & & & & 0 & & & \\
\hline 19 & 1 & NE-E & 1 & N-NW & 0 & & & \\
\hline 20 & 0 & & & & & & & \\
\hline 21 & 0 & & & & 0 & & & \\
\hline 22 & 0 & & 0 & & 0 & & & \\
\hline 23 & 0 & & 0 & & 0 & & & \\
\hline
\end{tabular}

Lava poured out from at least three sites on the caldera wall (Fig. 4): (i) on the northern and northeastern inner caldera walls, 30-40 m below the former Dolomieu caldera floor, at 2470-2460 $\mathrm{m}$ asl; (ii) on the eastern inner caldera wall, 10-20 m below the former Dolomieu caldera floor, at 2490-2480 m asl; (iii) on the southeastern inner caldera wall, 80-100 m below the former Dolomieu caldera floor, at 2420-2400 m asl. A fourth site may have existed on the western inner caldera wall below Bory crater because an occasional red glow was visible in the Bory webcam videos, implying the presence of incandescent lava below Bory crater.

Contemporaneous lava emissions from multiple locations also occurred during 6 April at sites on the northeastern and southeastern caldera rims and caldera floor (Fig. 4). The duration of lava emission was different at each emission site and ranged from $15 \mathrm{~min}$ to $>1 \mathrm{~h}$. Lava emissions were also characterised by visible fluctuations in the lava discharge rate. For example, over a 10-s time interval, discharge changed from relatively high and continuous to much lower and intermittent (Fig. 5).

During 7 April, intracaldera lava emissions occurred from different caldera-wall vents and discharge was not continuous, involving pauses up to $2 \mathrm{~h}$ long. Periods of lava emission were shorter than on the previous day, being 2 to $20 \mathrm{~min}$ long. During the $\sim 5$ h of lava emission between 00:07 and 05:04 GMT, discharge was noticeably unsteady, fluctuating between lower and higher rates (Supplementary Table S1). Also on 7 April, sudden increases in the lava discharge rate were observed from time to time. These sudden increases were suggested by wider and brighter emissions at different caldera-wall emission sites and lasted a few minutes. Lava emissions generated lava flows that were $\sim 2$ mide, tens of metres long (maximum observed length $\sim 100 \mathrm{~m}$ ), and shaped by gravity on the near-vertical caldera wall (Fig. 5).

Lava emission was also observed in the centre of the newly formed caldera floor on both 6 and 7 April (Fig. 4, Fig. 2b, c). The 6 April lava covered a small area $(\sim 20$ $\left.\mathrm{m}^{2}\right)$. At the same central eastern caldera floor site, lava 

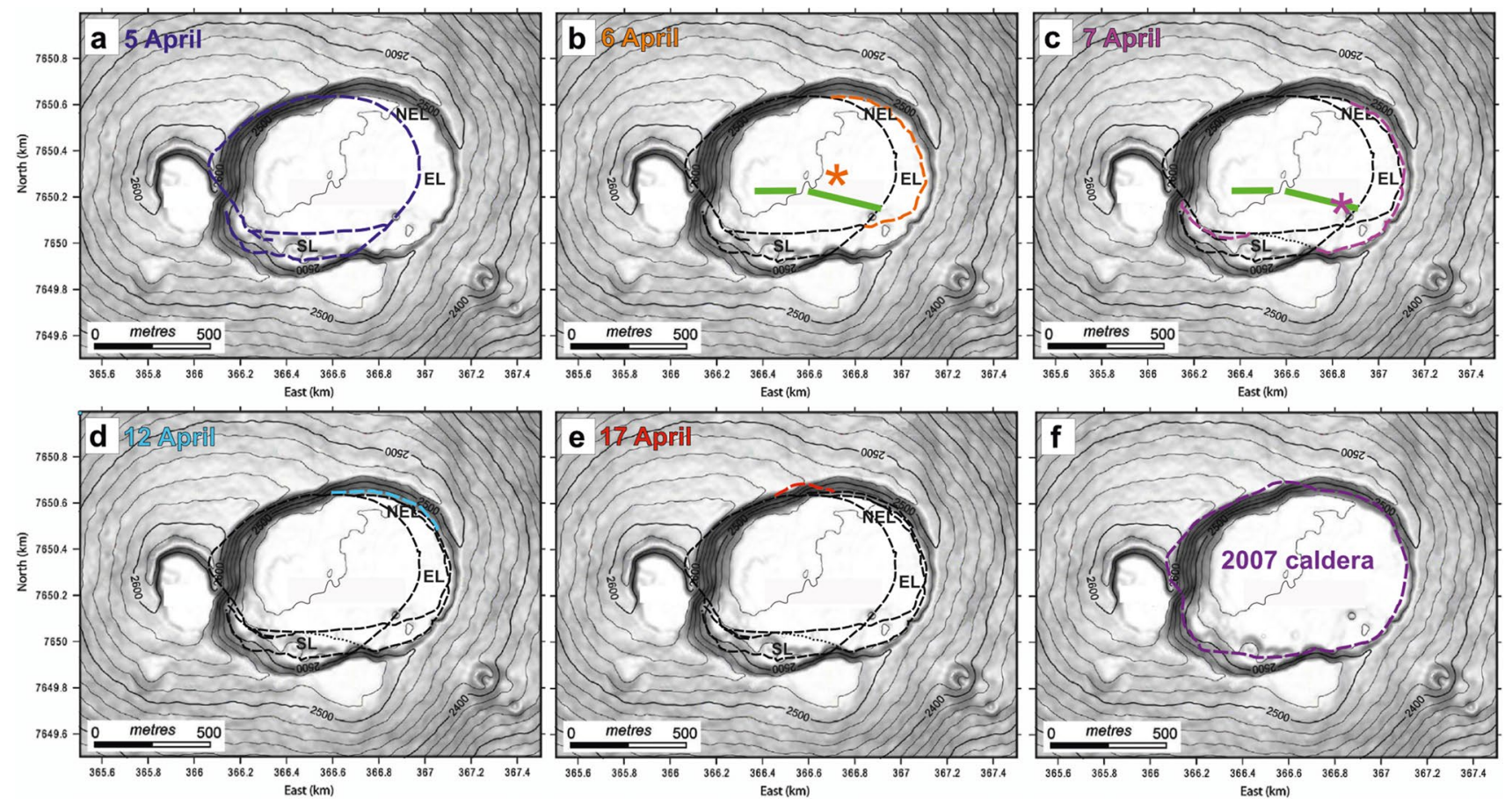

Fig. 2 Reconstruction of the main steps in the 2007 caldera collapse based on pre-2007 and syn- and post-caldera collapse images examined in this study. The background is the DEM of Piton de la Fournaise summit before collapse, modified from Michon et al. (2009). a Collapse on 5 April affected most of the Dolomieu caldera floor, leaving remnants as northeastern (NEL), eastern (EL) and southern (SL) ledges (dashed dark blue lines). b Part of the NEL and EL subsided further on the 6 April (dashed orange line). The orange asterisk gives the location of observed intracaldera effusive activity. c Subsidence on the 7 April affected the NEL, EL and different parts of the

spattering activity was recorded on 6 April at 15:39:06 GMT. On 7 April, lava emission was observed $200 \mathrm{~m}$ farther SE at $250 \mathrm{~m}$ below the former Dolomieu caldera floor (Fig. 2c). The lava emission sites on the new caldera floor on 6 and 7 April were close to the trace of the 18 February intracaldera fissure, and it is possible these vents were located on the 18 February structure.

\section{Ash and dust plumes}

We use "ash plume" for plumes generated by an explosion, and "dust plume" for plumes associated with landslides. Ash plumes lasted for a short time, typically $30 \mathrm{~s}$ to $5 \mathrm{~min}$, and rose at speeds of 10 to $20 \mathrm{~ms}^{-1}$, reaching heights up to $\sim 840 \mathrm{~m}$ above the explosion site although most rose only to $400 \mathrm{~m}$ or less. They were strongly focussed in a single, commonly vertical direction. The ash plumes varied in colour but were typically gray, dark gray or black (Fig. 6), implying they had much higher particle concentration than the transparent dust plumes.
SL (dashed pink lines). The pink asterisk gives the location of the observed south-southeastern effusive activity (about $250 \mathrm{~m}$ below the former caldera floor). d Collapse on the 12 April affected the remnants of the NEL and the Dolomieu caldera rim (dashed pale blue line). e Part of the northern rim of the Dolomieu caldera collapsed on the 17 April (dashed red line). $\mathbf{f}$ The dashed purple line gives the Dolomieu caldera as it was after the 17 April. The deepest point in the new caldera was $\sim 330 \mathrm{~m}$ below the former Dolomieu caldera floor. Pale green bars on $\mathbf{b}$ and $\mathbf{c}$ are the map trace of the 18 February 2007 intracaldera fissure (Staudacher et al. 2009)

Dust plumes rose more slowly at speeds of $\sim 3 \mathrm{~ms}^{-1}$, and were visibly transparent (Fig. 3), reflecting their low particle concentration. After formation, dust plumes were redirected or dispersed by wind after about $10 \mathrm{~s}$ to $1 \mathrm{~min}$, depending on plume size.

Three different types of ash plume were observed. The first type (lava-related) was generated by explosions at new lava emission sites on the caldera walls and comprised dark gray to black ash plumes that typically lasted 30-60 s (Figs. 5 and 6). Similar explosions and ash plumes occurred at lava emission sites after a sudden increase in the discharge associated with small-volume landslides. Explosions that occurred at active steam fumaroles produced the second plume type (fumarole-related), which were finger-like and gray to dark gray. These plumes spread rapidly, at $\sim 20 \mathrm{~ms}^{-1}$, in different directions and lasted up to $2 \mathrm{~min}$, after which white steam clouds appeared near the explosion site (Fig. 7). In several cases, explosions followed an increase in fumarole discharge (Fig. 7). The third type was much larger in volume than the other two types, filling most of the Dolomieu caldera or portions of the inner caldera (Fig. 8). These ash 
Fig. 3 Sequence of photographs capturing a landslide that affected the eastern caldera wall on 7 April 2007. A dust plume triggered by the landslide rose a few hundred $\mathrm{m}$ above the caldera rim and was then dispersed to the north by wind. Photos taken by the Bory webcam located $\sim 500 \mathrm{~m}$ due west of the centre of Dolomieu caldera, OVPF monitoring network. White scale bar on all photos is $\sim 100 \mathrm{~m}$

plumes lasted at least a few minutes, were dark gray to black, suggesting a high particle concentration, and rose rapidly, at $\sim 20 \mathrm{~ms}^{-1}$. This plume type was associated with significant increments in caldera collapse and is thus labelled "collapserelated" (Fig. 8).

\section{Intracaldera fumaroles}

White steam fumaroles were noted prior to, during and after caldera collapse events. Fumaroles were present on the Dolomieu caldera floor aligned on fractures (Fig. 4), and along fracture zones at the caldera rim. They fluctuated in the amount of steam emitted, for example, increasing in steam emission prior to an explosion (Fig. 7). Intracaldera wet talus was observed immediately after several collapse phases, as was noted in Lénat et al. (2012a). These observations suggest caldera collapse exposed a very shallow water table and/or the upper part of the hydrothermal system of the volcano (Lénat et al. 2012a, b).

\section{Correlation between seismic signals and observations of intracaldera events}

Spectrograms of the seismicity during the period 5-7 April show an evolution from tremor to cyclic volcano-tectonic seismicity (Staudacher et al. 2009). Spectrogram peaks after the end of the cyclicity on 7 April coincided with mild collapse-related explosions and intracaldera landslides and showed no such distinctive pattern. Seismic cyclicity was interpreted by Michon et al. (2007) and Staudacher et al. (2009) to reflect increments in caldera collapse and was correlated with deformation data. We compared collapse increments and intracaldera landslides and explosions as identified from the OVPF webcam videos during this period, 5-7 April, with seismic signals recorded by the OVPF seismic network (Fig. 9). There is a strong correlation between observed caldera collapse increments and explosions, and the peaks of the cyclic portion of the spectrogram during 6 and 7 April until 00:48 GMT when seismic cyclicity ended (Fig. 9). Many of the explosions coincided with opening of new lava emission sites or increases in discharge at existing sites, so it can be argued that there was also a correlation between lava emissions and peaks in the cyclic part of spectrogram. Also, higher frequency peaks were mostly associated with explosions whereas lower frequency peaks were related to landslides (Fig. 9).

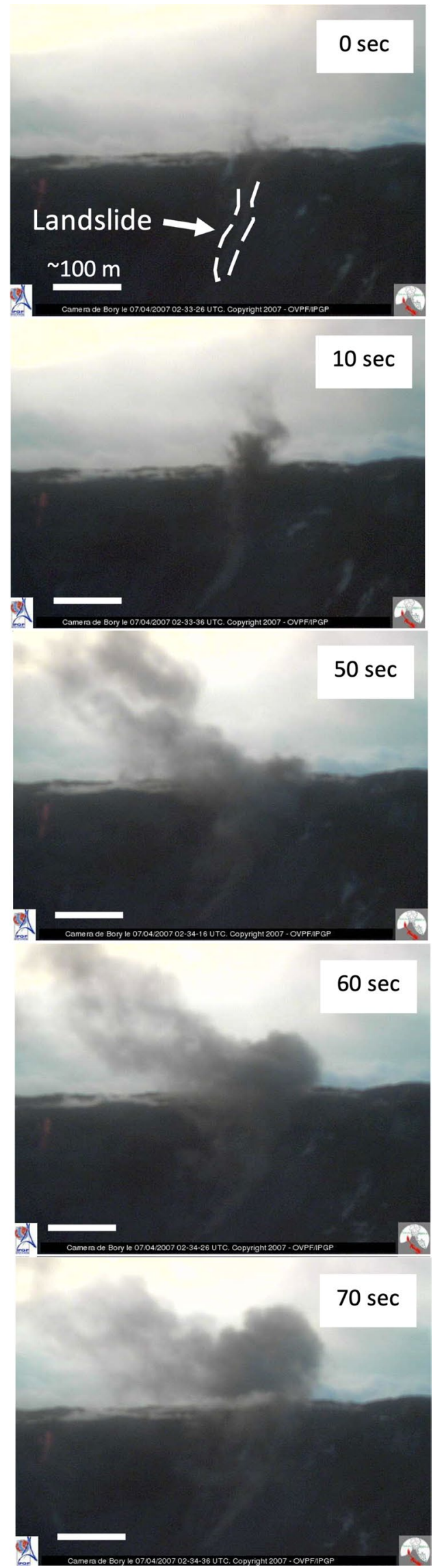




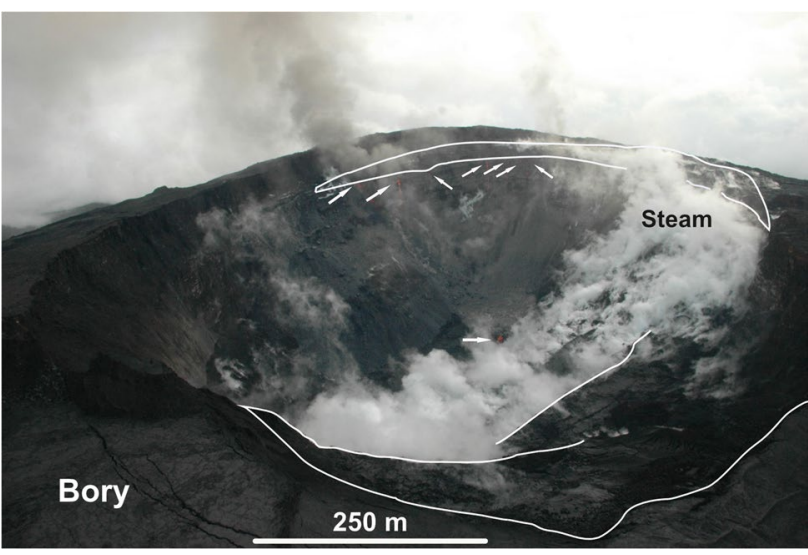

Fig. 4 Dolomieu caldera on the 6 April after major collapse of the caldera on the previous day, viewed toward the northeast. The remnants of the former caldera floor are visible (white lines). Multiple lava emission sites (white arrows) were active on the northeastern caldera wall and one on the caldera floor. Numerous steam fumaroles were present on the southeastern caldera wall, some of them aligned along fractures. Photo taken by Gendarmerie Nationale, OVPF database

\section{Proximal ash deposits from ash plumes generated during caldera collapse}

OVPF staff noted a pinkish ash layer $<2 \mathrm{~cm}$ thick covering Bory crater and the nearby summit when they visited on 8 April (Fig. 10a). This ash was new and very wet, and found to directly overlie lava or older pyroclastic deposits on the floor of Bory crater. This ash deposit can be therefore confidently correlated with the summit events of the preceding days. Sections through the proximal ash deposits sampled in 2009 comprise five beds (in ascending order, brown, lower black, pink, upper black, gray-brown) (Fig. 10b, c). Five different components are present in every bed although abundances are different in each of the five beds (Table 3 ). The five components are as follows:

(1) Basalt clasts; the basalt clasts are equant in shape, black, microcrystalline, and plagioclase-rich and/or oxide-rich (Fig. 11a);

(2) Olivine, pyroxene and plagioclase crystals;

(3) Glass shards; the glass shards are dark brown to clear, fluidal to blocky and cuspate, and moderately vesicular to non-vesicular (Fig. 11a, c, d, e);

(4) Red clasts; this category includes both pervasively red and red-rimmed glass fragments, basalt particles and crystals (Fig. 11b);

(5) Pele's hair fragments.

The brown bed at the base is $5 \mathrm{~mm}$ thick and composed of extremely fine to medium ash $(0.063-0.5 \mathrm{~mm})$. Basalt clasts and crystals are the most abundant components, together amounting to $~ 80$ modal\% (Table 3 ). The brown bed is overlain by a 1.5 -mm-thick, laminated lower black bed of extremely fine to fine ash $(0.063-0.25 \mathrm{~mm})$. The black bed is vesicular (Fig. 11b). Vesicles have irregular amoeboid shapes and are typically $<1 \mathrm{~mm}$ in maximum dimension. The most abundant components in the lower black bed are black basalt fragments ( 45 modal\%; Table 3$)$. A pink, 1.5-mm-thick, weakly laminated bed of extremely fine to medium ash $(0.063-0.5 \mathrm{~mm})$ overlies the lower black bed. The pink colour reflects the high abundance ( $\sim 50$ modal $\%)$ of red clasts in this bed. The pink bed is overlain by the upper black bed which is in fact less than $1 \mathrm{~mm}$ thick and consists of extremely fine to fine ash. The upper black bed could not be sampled without contamination by adjacent beds so the componentry is not accurately known. However, the black colour most likely reflects a high abundance of black basalt clasts, similar to the lower black bed. The graybrown bed at the top is $5 \mathrm{~mm}$ thick and consists of extremely fine to very coarse ash $(0.063-2.0 \mathrm{~mm})$. In this bed, glass particles ( 35 modal $\%)$, crystals ( 25 modal $\%$ ) and red particles ( 25 modal\%) have similar abundances (Table 3$)$. The gray-brown bed is internally laminated and, in many cases, the laminae are lenticular.

\section{Juvenile versus non-juvenile pyroclasts in the proximal deposits}

Of the five particle types in the proximal ash deposits, some of the glass particles and the Pele's hair fragments are considered to be juvenile, i.e., particles derived directly from fragmentation of molten magma. The clear glass shards (sideromelane) and the dark brown, opaque glass shards (tachylite) that have fluidal shapes and are vesicular could be juvenile. Such shards are not common, amounting to $<15$ modal\% of the whole proximal ash deposits. The origin of other glass shards that are not fluidal in shape and that are sub-rounded is uncertain. They could also be juvenile but formed by brittle fragmentation and recycled through the vent, or they could be non-juvenile clasts and have a pre-April 2007 origin. The Pele's hair fragments are delicate sideromelane fibres only tens of microns across and would have been generated directly from airborne droplets of molten basalt. They are present throughout the proximal ash deposits, though their abundance is low (1 modal\%).

The red particles, basalt particles and some of the crystals are considered to be non-juvenile. The red colour of the red particles is the result of oxidation, in response to surface weathering, prior thermal oxidation of summit basalt and/ or interaction with the summit hydrothermal system. The red particles are most abundant in the third ash bed, thus imparting the pink colour. 

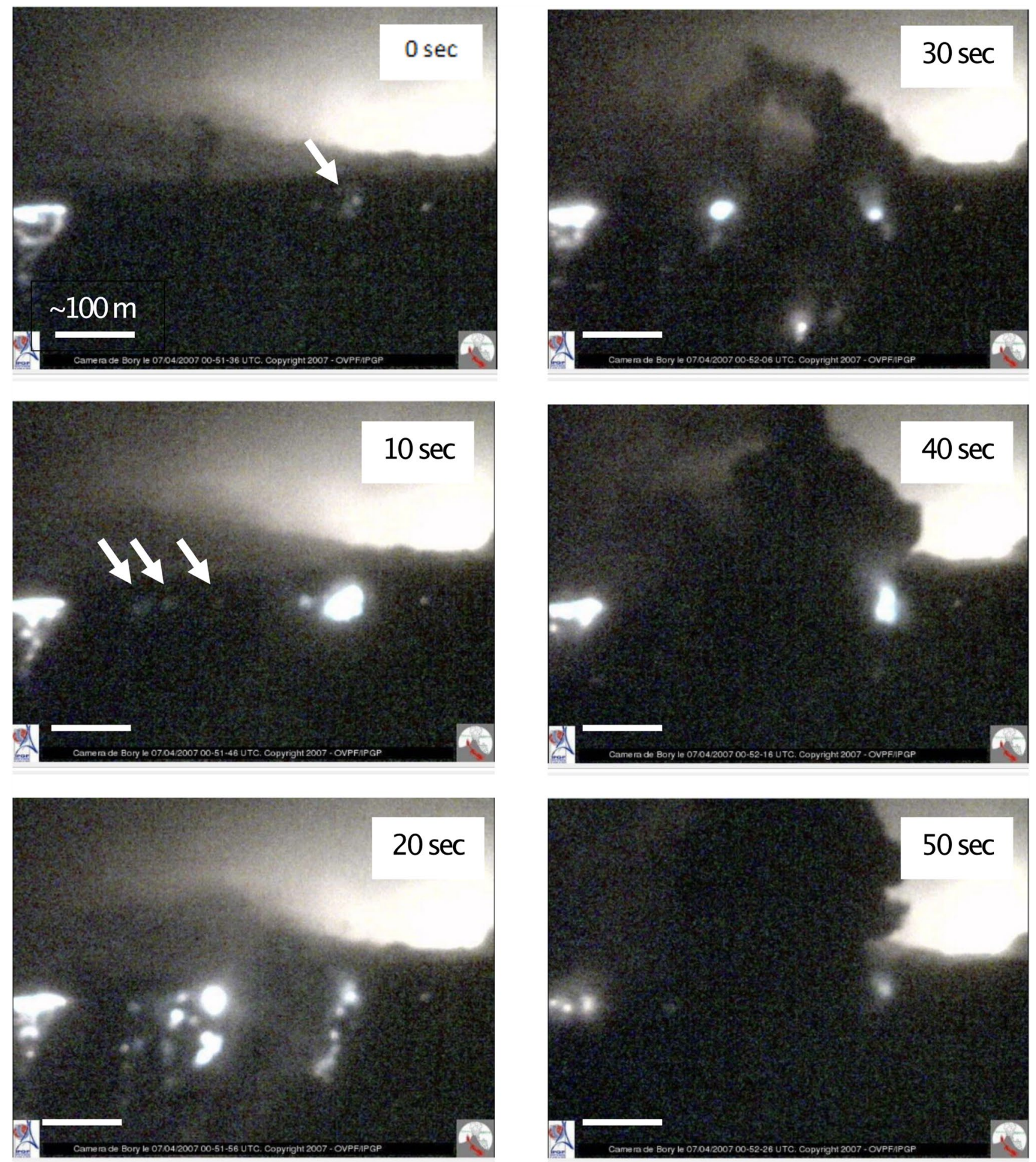

Fig. 5 Sequence of photographs capturing new lava emission sites (white arrows in the first two frames) on the eastern caldera wall on 7 April. Lava emission sites near the top of the caldera wall and lavas flowing down the caldera wall appear as bright spots. The last

three frames also show a dark ash plume generated by an intracaldera explosion. Photos taken by the Bory webcam, OVPF monitoring network. White scale bar on all photos is $\sim 100 \mathrm{~m}$ 

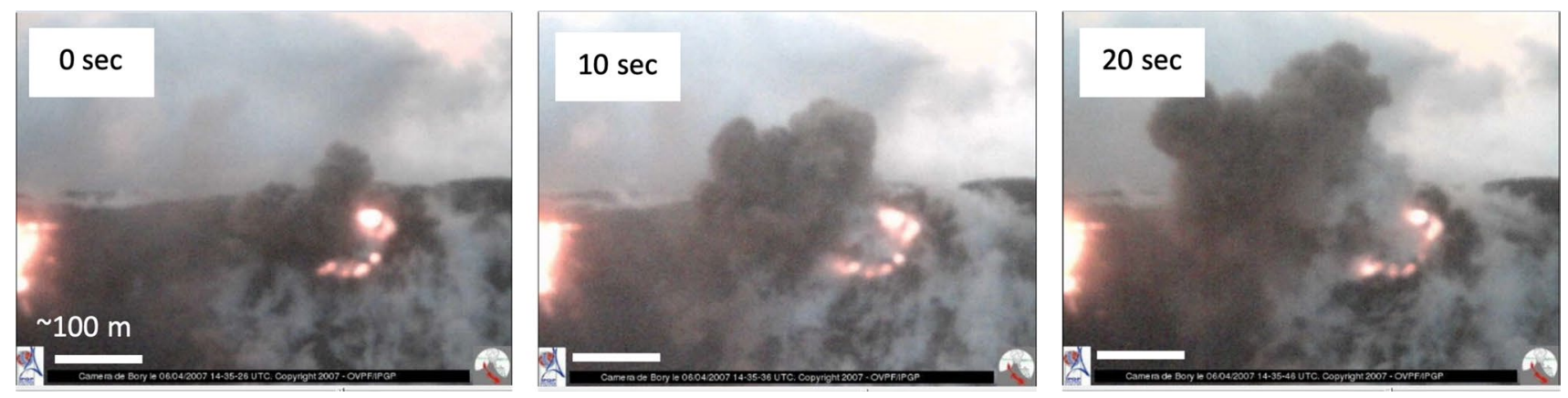

Fig. 6 Sequence of photographs capturing an explosion related to a new lava emission site on the eastern caldera wall on 6 April. Photos taken by the Bory webcam, OVPF monitoring network. White scale bar on all photos is $\sim 100 \mathrm{~m}$

The plagioclase-rich nature of the black basalt fragments suggests they are derived from pre-2007 basalt at the summit because the 2007 products are strongly olivine-phyric and almost devoid of plagioclase (Di Muro et al. 2014). Also, the oxide-rich clasts have been altered, most likely through interaction with the summit hydrothermal system. Many of the free crystal fragments have partly altered rims and, given the mixture of crystal types (olivine, pyroxene, plagioclase), they are unlikely to be juvenile. It remains possible that some fresh olivine crystal fragments are juvenile and derived from 2007 olivine-phyric basalt.

\section{Source of Pele's hair fragments in the proximal ash deposits}

Although Pele's hair fragments are likely to be juvenile, they are not necessarily the products of summit explosions. Pele's hair fragments in the proximal ash deposits could have been blown from contemporaneous high fountains active at lower altitude at Piton Tremblet, rather than being produced by summit activity. The Piton Tremblet vent is only $7.5 \mathrm{~km}$ from the summit and at $590 \mathrm{~m}$ asl. Between 5 and 7 April, fountains reached $>300 \mathrm{~m}$ in height and related plumes were 900 to $>2000 \mathrm{~m}$ in height (Vergani 2018). During the same period, ash from Piton Tremblet was periodically dispersed over the volcano summit. Pele's hair from high fountains at Piton Tremblet was deposited widely elsewhere on the island (Staudacher et al. 2009) so it is most likely that the Pele's hair in the proximal ash deposits came from that source.

\section{Discussion}

\section{Correlation of proximal ash deposits with caldera collapse events}

The brown ash bed at the base of the proximal ash deposits corresponds to the initiation of caldera collapse on 5
April. Unfortunately, activity on 5 April was not visible from the OVPF webcam network. The high abundance of non-juvenile components in this bed suggest that it was deposited from dust plumes related to subsidence and landslides, and perhaps also ash plumes from phreatic explosions.

The lower black ash bed was deposited between 6 April and early 7 April. During this period, black ash plumes accompanied collapse events and explosions that affected the eastern, southeastern, southern and western sectors. The black ash plumes were related to the opening of lava emission sites and fluctuating lava discharge (Fig. 12a). Fluidal and teardrop-shaped sideromelane fragments probably resulted from the involvement of lava in explosions at the different lava emission sites on the caldera wall and the mild magmatic explosive activity on the caldera floor.

The pink bed is related to collapse events and explosions starting at 08:18:06 GMT on 7 April when pink ash plumes were common, and the wind dispersed ash over the inner Bory crater. The abundance of red oxidised and altered particles in the pink bed suggests that the explosions were mainly phreatic, involving the interaction of hot rock and water from the summit hydrothermal system (Fig. 12b).

The gray-brown bed at the top contains multiple laminae. The laminae are probably deposits from successive dust plumes generated by multiple landslides beginning at 11:05:00 GMT on 12 April (Fig. 12c). No explosiongenerated ash plumes formed during this period.

Thivet et al. (2020) reported the componentry of an ash layer considered to correlate with the 2007 caldera collapse. The bulk sample came from a site $2 \mathrm{~km}$ west of the caldera centre. They found the sample comprised $99 \mathrm{wt} . \%$ variably altered, non-juvenile components. The brown and pink beds in the Bory crater ash deposit are both dominated by non-juvenile components (Table 3), and either or both could be the proximal equivalent of the ash sampled by Thivet et al. (2020). 
Fig. 7 Sequence of photographs showing intracaldera steam fumaroles on the eastern caldera wall on 7 April. An increase in steam emission (at $\sim 40 \mathrm{~s}$ ) was followed a minute later by an explosion comprising a rapidly rising plume. Photos taken by the Bory webcam, OVPF monitoring network. White scale bar on all photos is $\sim 100 \mathrm{~m}$

\section{Timing, frequency and types of caldera collapse events}

Collapse affected different portions of the floor and rim of the former Dolomieu caldera during the period from 5 April until 17 April (Table 2, Fig. 2). The largest collapse event in terms of volume occurred on 5 April $\left(\sim 91 \times 10^{6} \mathrm{~m}^{3}\right.$; Derrien et al. 2020), and additional significant collapse events continued until early on 8 April. Hence, the period from 5 April to early 8 April was the main episode of caldera collapse. Subsequently, there was a gradual decrease in the frequency and volume of collapse events. After the main episode of collapse, the total volume involved in all subsequent collapse events was in the range $18-24 \times 10^{6} \mathrm{~m}^{3}$ (Michon et al. 2007; Urai et al. 2007; Staudacher et al. 2009; Derrien et al. 2020), roughly $20 \%$ of the volume of the initial collapse on 5 April.

In our study, observed ash or dust plumes lasting $>10 \mathrm{~s}$, lava emissions and landslides have also been included in the collapse event chronology. Incorporating these phenomena is important because a significant number of collapse events involved simultaneous lava emissions, explosions and landslides (Figs. 4-6 and 9). On this basis, 70 events were observed in this study during 6 to 7 April alone (Supplementary Table S1; Vergani 2018). Other studies have focussed on collapse increments evident in a single dataset, and have not included lava emissions, explosive eruptions and landslides. For example, using seismic data, 38 collapse events were recognised between 5 and 7 April by Michon et al. (2011). Using seismic and tilt data, 44 collapse events were recognised between 5 and 8 April by Fontaine et al. (2014). Using very-long-period seismic data, 48 collapse events were recognised between 5 and 14 April by Fontaine et al. (2019). All studies, including ours, agree on caldera collapse having involved multiple steps, reflecting gradual adjustment of the rock column below the newly formed caldera to rapid magma withdrawal from the summit reservoir by means of the Piton Tremblet flank eruption.

During the period 5 to 17 April, most of the collapse events involved landslides that generated dust plumes. Landslides mainly involved subsidence of unstable portions of the caldera walls and rim and remobilisation of talus inside the caldera. Small-volume focussed explosive ash plumes (lava-related and fumarole-related) were also frequent during the same period (Figs. 6 and 7). Collapse-related explosive ash plumes involving a large part of the volcano summit were mainly associated with major collapses during 6 and 7 April (Fig. 8). On 6 April, 80\% of the collapse events were
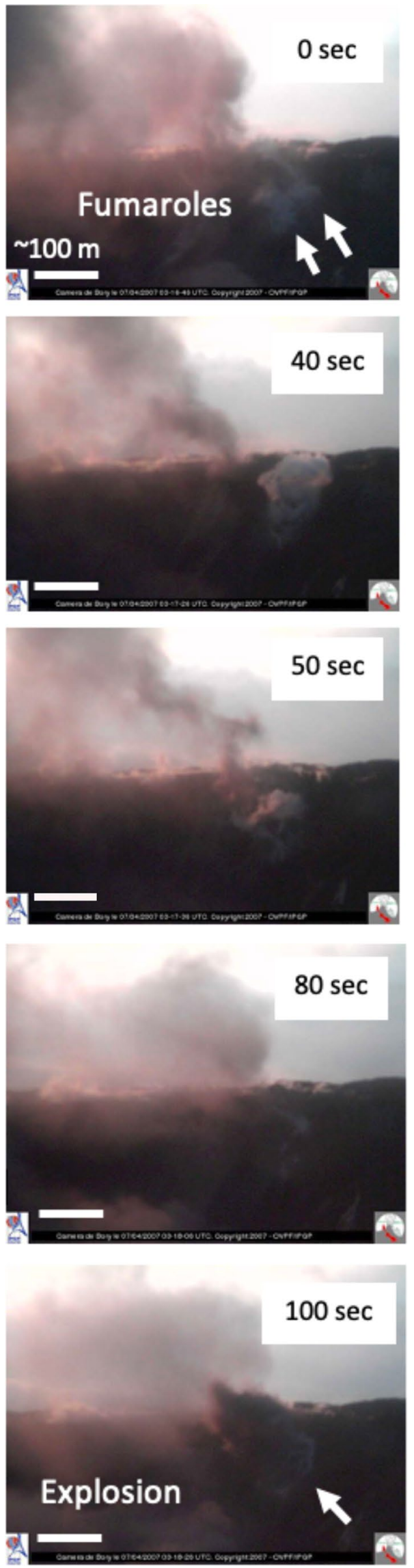


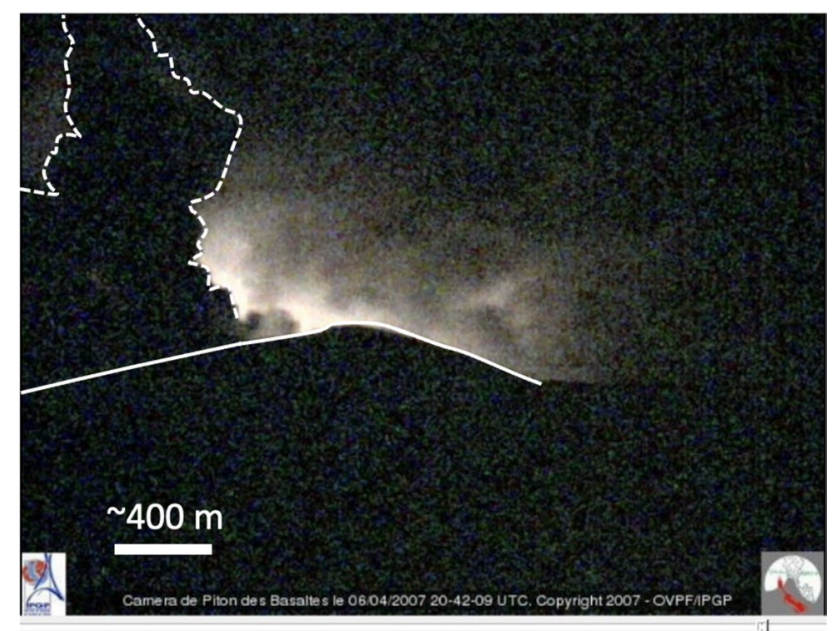

Fig. 8 Large ash plume (white dotted line) from an explosion related to caldera collapse on 6 April, viewed from the Piton Basaltes webcam (OVPF database). The caldera lies beyond the white solid line. The total duration of the ash plume was $370 \mathrm{~s}$ (20:38:59-20:45:09 GMT)

associated with explosive activity and on 7 April, $45 \%$ of the collapse events were associated with explosive activity. The observed explosions and seismic spectrograms of volcanotectonic earthquakes show a perfect fit (Fig. 9), demonstrating that explosions and seismicity were an integral part of the caldera collapse process.

In addition, on 6 and 7 April, there was an increase in the frequency of opening of intracaldera lava emission sites at different locations and heights, and discharge rates were highly variable. The observed intracaldera lava emissions and their fluctuations during 6 and 7 April were in many cases associated with collapse events, explosions and the production of ash plumes, all occurring in matter of minutes. For example, on 6 April at 16:35 GMT, a northeastern lava emission site was active and a new north-northeastern lava emission site opened. At 16:36 GMT, there was an increase in discharge rate followed by an explosion that produced a black ash plume. Two minutes later, at 16.38 GMT, major collapse of the north-northeastern Dolomieu caldera floor occurred.

\section{Source of magma for the intracaldera lava emissions}

The numerous intracaldera lava emissions (Figs. 4 and 5) associated with collapse events on 6 and 7 April have been interpreted by other authors to be derived from still-molten pockets of lava that had ponded within the former Dolomieu caldera during the 2006 (August-December) and early 2007 (February) eruptions. These pockets of lava were proposed to have been subsequently released by collapse of the caldera floor (Michon et al. 2007; Urai et al. 2007; Staudacher et al. 2009). However, as we argue next, an alternative explanation is that the lava originated from a shallow intrusion emplaced beneath the eastern flank of the volcano summit at the end of March 2007 and intersected by caldera collapse.

Summit deformation data acquired before and during the initial eruptive activity of 30 March showed an increase in inflation on the eastern summit flank, encompassing the northeastern, eastern and southeastern sectors. The displacement was interpreted to indicate intrusion of two dykes to the north and south on the eastern side of the summit (Peltier et al. 2009a, b; Staudacher et al. 2009; 2016; Froger et al. 2016). The southern dyke reached the surface at $1900 \mathrm{~m}$ asl and fed the eruptive activity of the 30 March (Peltier et al. 2009a; Staudacher et al. 2009; Froger et al. 2016), whereas the northern dyke fed a shallow intrusion (Peltier et al. 2009b). This intrusion below the eastern to northern sector of the volcano summit, close to the original Dolomieu caldera rim, could have been the magma source for the lava emissions when intersected by caldera collapse (Fig. 12a). Furthermore, the recorded cyclic summit inflation and deflation of $\sim 20-40$ microradians during 5 to 7 April (Michon et al. 2007; Peltier et al. 2009a; Staudacher et al. 2009) suggests this magma reservoir was being periodically recharged and discharged. This hypothesis is supported by:

(a) The confinement of directly observed lava emission sites to the northern to southeastern intracaldera sectors, showing close correspondence with the intrusion location,

(b) Lava emission from multiple sites on the caldera wall at different heights (from 20 to $>100 \mathrm{~m}$ below the former Dolomieu caldera floor),

(c) The observed fluctuations in discharge, and

(d) The different timing and duration of lava emission events.

\section{Magma involvement during collapse-related explosive eruptions?}

The collapse-related explosions that occurred during 6 and 7 April have previously been interpreted as phreatic (hot-rock-water interaction; Michon et al. 2013). However, syn-eruptive recordings clearly show a close spatial and temporal association of explosions with the opening of lava emission sites and lava discharge fluctuations. Also, the proximal ash deposits include fluidal sideromelane particles that are likely to be juvenile. Hence, we infer that some explosions, particularly those linked to lava emission, were phreatomagmatic. Collapse events, lava emission and phreatomagmatic explosions were intricately interdependent: collapse was integral in the release of trapped magma and probably also triggered local ingress of water, providing circumstances where magma-water interaction could drive an explosion. 


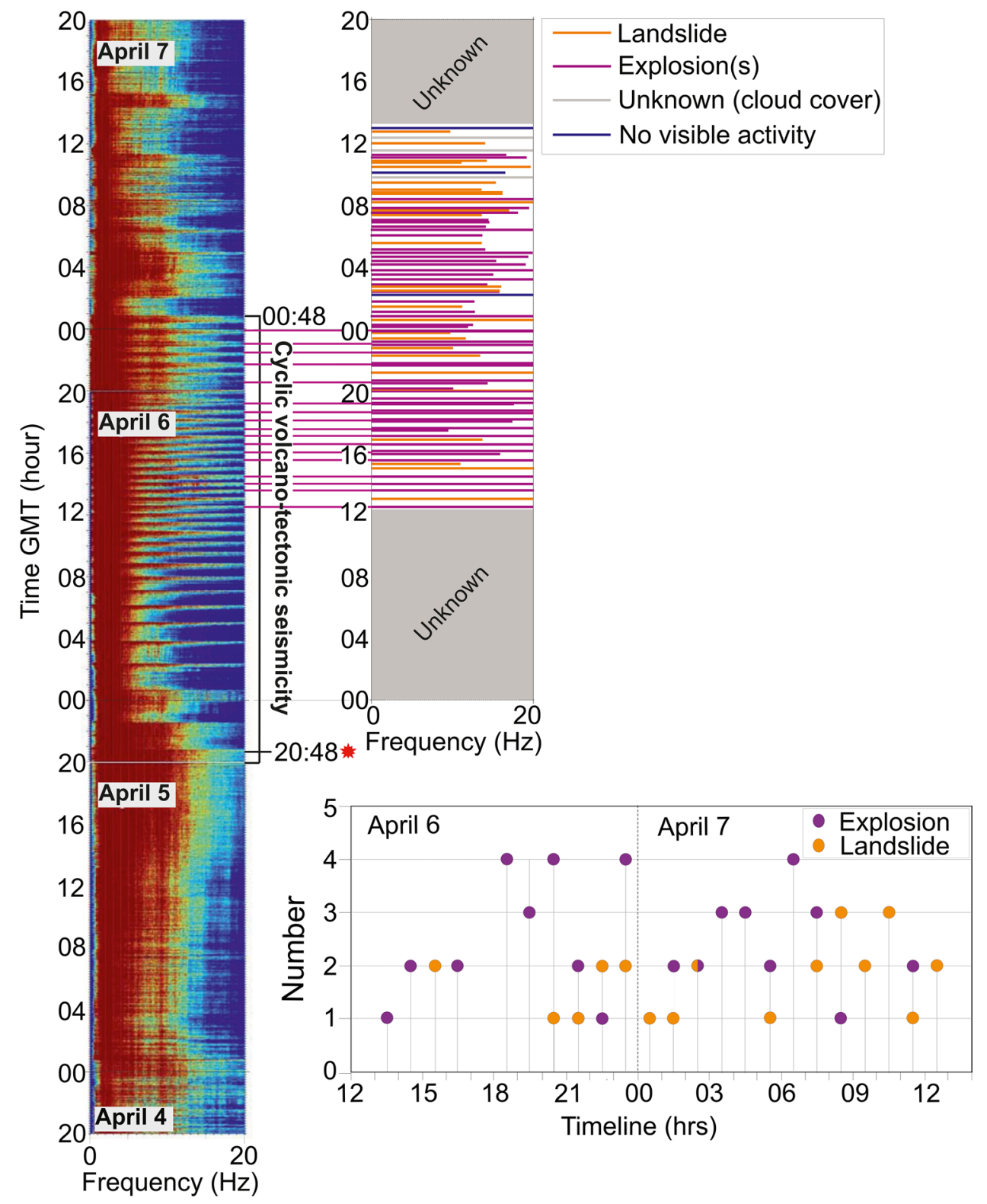

Fig. 9 On the left side, seismic spectrograms recorded by the OVPF monitoring network during the period late 4 to 7 April, modified from Michon et al. (2007). Signals up to $5 \mathrm{~Hz}$ correspond to volcanic tremor; signals between 5 and $15 \mathrm{~Hz}$ are interpreted as the vibration of the edifice; the short-time signals between 0 and $20 \mathrm{~Hz}$ indicate volcano-tectonic events (following Michon et al. 2007) including collapse, explosions and landslides. Seismic cyclicity that coincided with caldera collapse events began on the 5 April at 20:00 GMT and ended on 7 April at 00:48 GMT. The red asterisk is the first major collapse that occurred on the 5 April at 20:48 GMT. The diagram on the right shows the sequence of explosions (purple) or landslides

\section{Implications for hazards and models of magma reservoirs}

The connection between summit caldera collapse and eruptions at flank vents on basaltic volcanoes is well (orange) corresponding to the seismic spectrogram peaks. Blue lines mark seismic spectrogram peaks for which there was no observed summit activity. Gray lines mark spectrogram peaks that coincide with periods of poor visibility or a lack of videos. The lengths of the coloured lines match the frequencies of the recorded volcano-tectonic events, as shown in the original seismic spectrogram from Michon et al. (2007). Each seismic spectrogram peak during the period of seismic cyclicity corresponds exactly to explosions (connected by a purple line) and/or collapses observed on the videos. The histogram (bottom right) shows the number of explosions (purple) and landslides (orange) through time

established from observed examples such as Fernandina (1968; Simkin and Howard 1970), Miyakejima (2000; Geshi et al. 2002) and Kilauea (2018; Neal et al. 2019; Anderson et al. 2019). In all cases, summit caldera collapse has been shown or inferred to result 

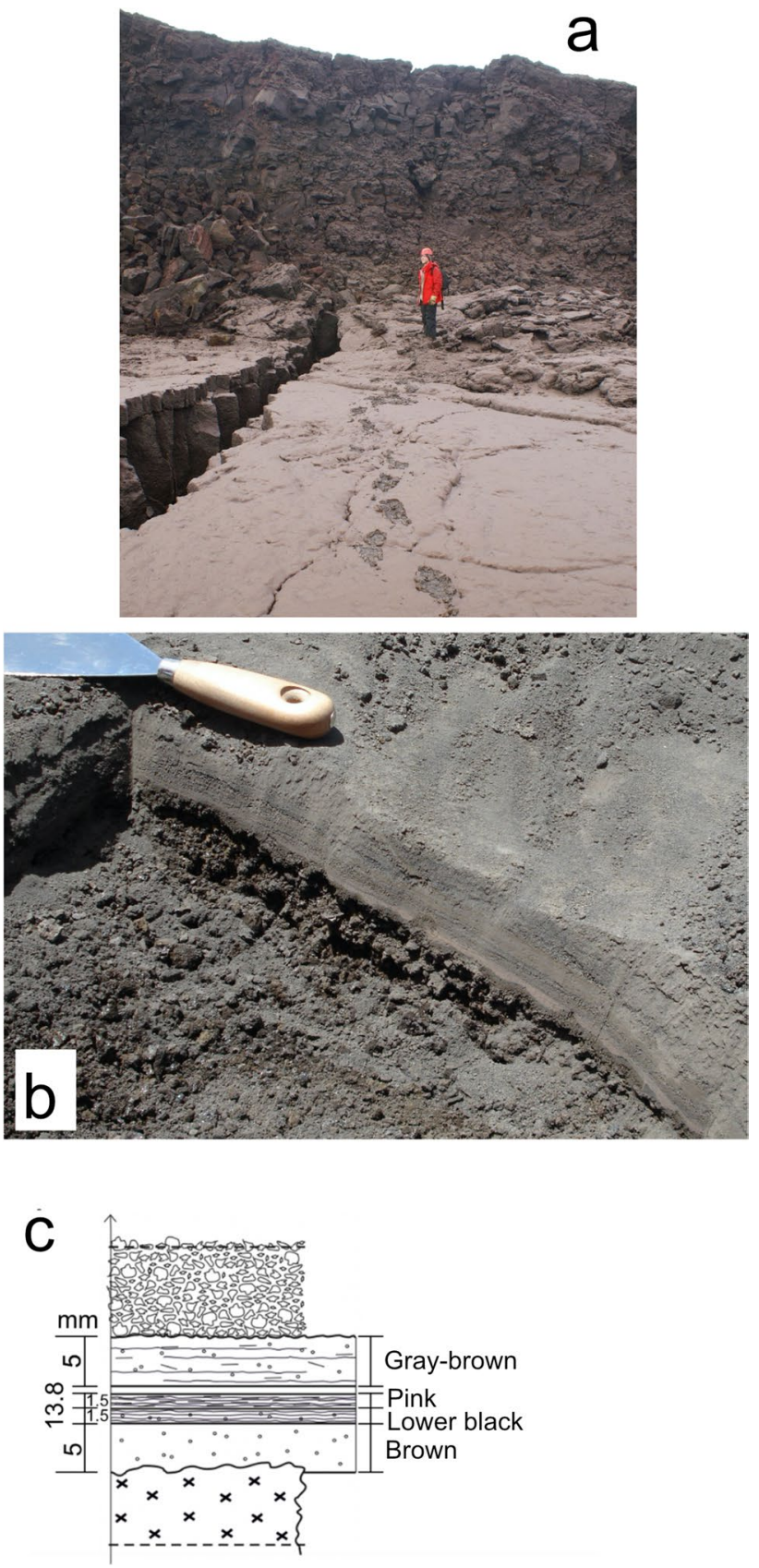

Fig. 10 a Pink wet ash deposit on the floor of Bory crater. Photograph taken 8 April 2007 by OVPF staff; OVPF database. b Proximal ash deposit in the southeastern corner of Bory crater. Photograph taken in 2009. c Stratigraphy of the proximal ash deposits. The upper black bed lies between the pink and gray-brown beds from draining of magma from the summit magma reservoir, and this relationship also applies in the case of the 2007 Piton de la Fournaise caldera collapse (Staudacher et al. 2009).

Despite the evidence for magma withdrawal from the summit reservoir, we have shown that magma was involved in intracaldera eruptions during the Piton de la Fournaise summit caldera collapse. The involvement of magma in syn-collapse intracaldera eruptions was also proposed at Fernandina and Miyakijima. At Fernandina, Simkin and Howard (1970) described a pink-red underside of the ash plume on 11 June 1968 and red flashes were observed through the ash plume during the night, suggesting incandescent lava and/or pyroclasts had been erupted in the caldera. At Miyakejima, Geshi et al. (2002) and Geshi and Oikawa (2008) described pyroclastic deposits related to the 18 August 2000 activity inside the caldera and these pyroclastic deposits included significant proportions of juvenile clasts. The explosions that accompanied caldera collapse at Kilauea produced lithic ash; however, a magmatic influence is suspected from the high volume of sulfur in gasses released at the same time (Neal et al. 2019). Hence, although phreatic explosive activity is well established as a hazard accompanying caldera collapse, phreatomagmatic explosions must also be expected.

Syn-collapse intracaldera lava emissions such as those observed at Piton de la Fournaise in 2007 have not been reported from the Fernandina, Miyakejima or Kilauea summit caldera collapse events (Simkin and Howard 1970; Geshi et al. 2002; Neal et al. 2019). Such lava emissions add to the intracaldera hazards accompanying summit caldera collapse at basaltic volcanoes.

The intracaldera lava emissions have the further significance of indicating the complexity of summit magma storage at Piton de la Fournaise. The inferred source of the intracaldera lava emissions was an intrusion under the eastern summit identified by Peltier et al. (2009b) and we have argued that the observed fluctuations in lava discharge and in the number and locations of emissions reflect dynamic recharge of magma into that intrusion (cf., Michon et al. 2007; Urai et al. 2007; Staudacher et al. 2009). If correct, the implication is that this reservoir was connected to a deeper reservoir in a complex way. Recharge must have largely by-passed the shallow magma
Table 3 Componentry in modal percent of the proximal ash deposits. Italicized columns give modal percent of dark versus clear glass. Estimates have an accuracy of \pm 5 modal $\%$

\begin{tabular}{lllllll}
\hline Bed & Crystals & Basalt clasts & Red clasts & Glass & Dark glass & Clear glass \\
\hline Gray-brown & 25 & 15 & 25 & 35 & 20 & 15 \\
Pink & 25 & 5 & 50 & 20 & 10 & 10 \\
Lower black & 20 & 45 & 5 & 30 & 15 & 15 \\
Brown & 35 & 45 & 5 & 15 & 10 & 5 \\
\hline
\end{tabular}



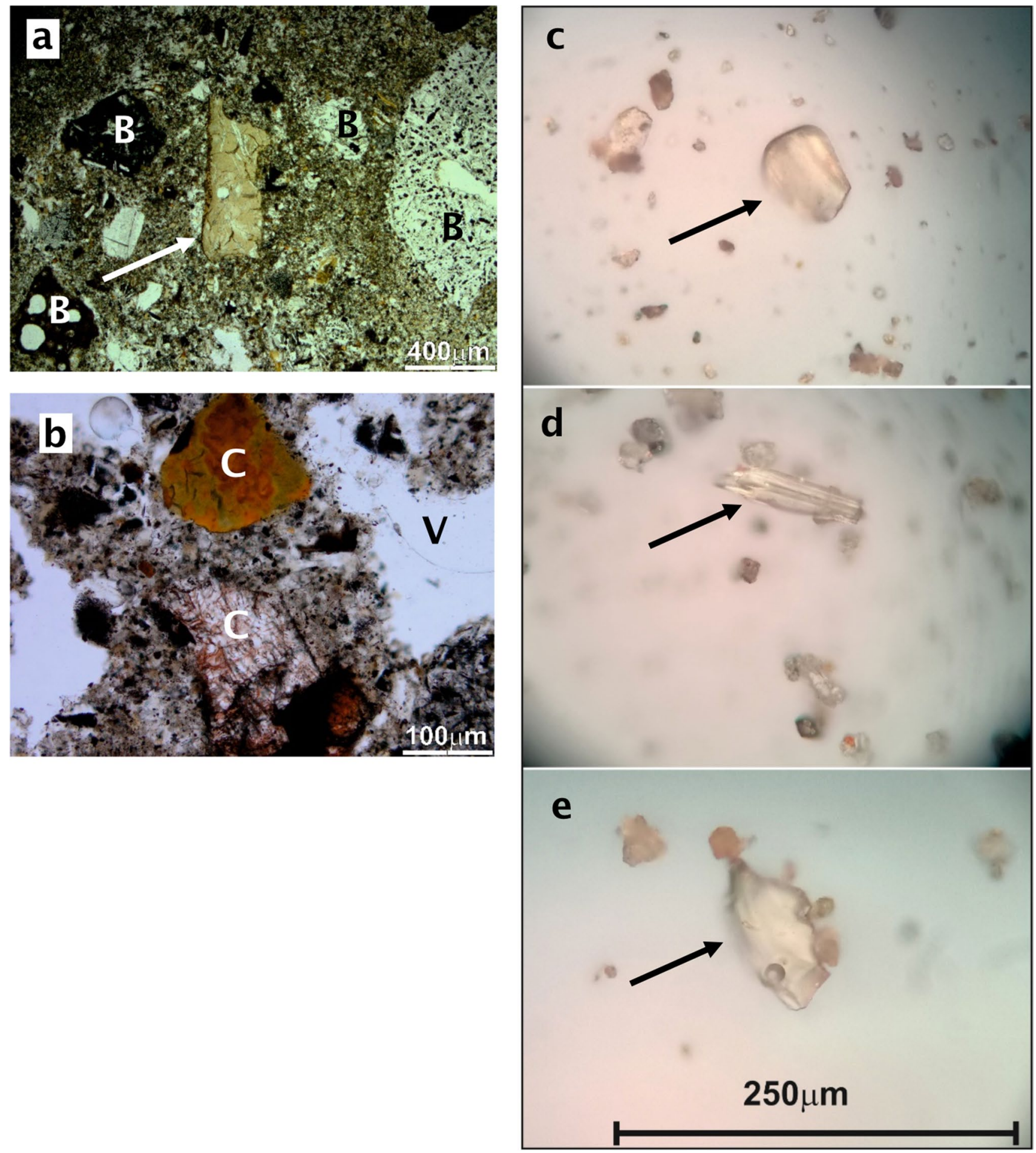

Fig. 11 Components in the summit ash deposit. a Plane-polarised light photomicrograph of a sample from the gray-brown bed, showing non-juvenile basalt fragments (B) and a brown glass fragment (white arrow). b Plane-polarised light photomicrograph of a sample from the

reservoir below the caldera which was being progressively drained by the Piton Tremblet flank eruptions. This conclusion adds further complexity to models of the magma

lower black bed, showing crystals (C) with a red surface coating and red tint along cleavage planes. $\mathrm{V}$, open pore in the ash layer. c, d, $\mathbf{e}$ Clear glass particles (sideromelane; black arrows) in the lower black bed. These particles are interpreted to be juvenile

plumbing system beneath Piton de la Fournaise. Similar complexity in magma storage and connections may be expected at other basaltic volcanoes. 

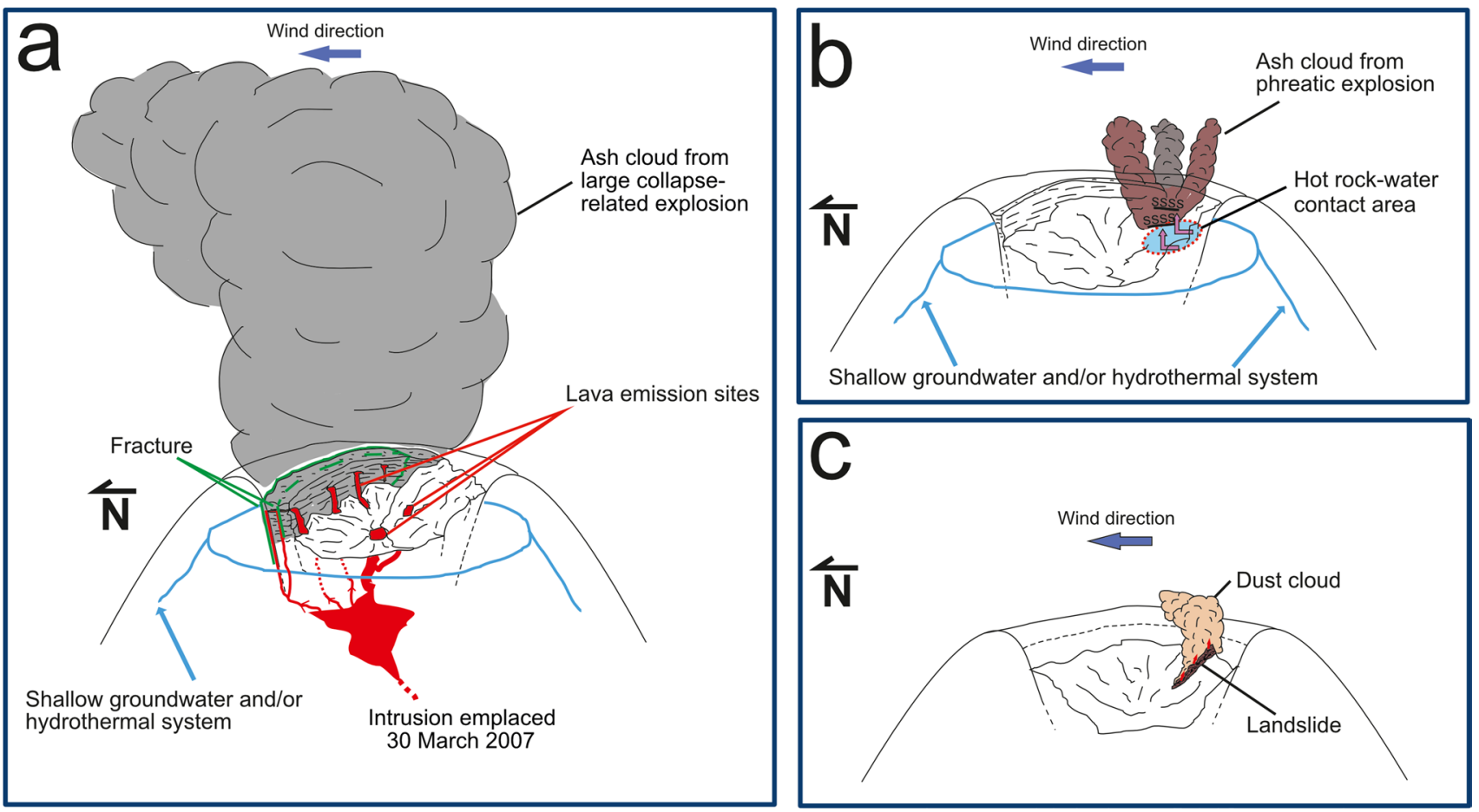

Fig. 12 Cartoons showing the main intracaldera activity that accompanied the 2007 Dolomieu caldera collapse. a Large, dark gray, particle-rich ash plumes rose for hundreds of metres above the explosion site. Such explosions were associated with collapses of significant portions of the former Dolomieu caldera and with intracaldera lava emissions. These explosions may have been phreatomagmatic, involving shallow intrusions and/or the intracaldera lavas and freshly exposed shallow groundwater and/or hydrothermal system. b Rela-

\section{Conclusions}

The 2007 Piton de la Fournaise caldera collapse involved numerous intracaldera lava emissions, explosions and landslides. Lava emissions occurred at multiple sites at different elevations on the caldera wall and discharge fluctuated markedly. Lava emissions were most likely sourced from the recently emplaced intrusion beneath the eastern summit of the volcano that was progressively and repeatedly exposed as the caldera floor subsided (cf., Michon et al. 2007; Urai et al. 2007; Staudacher et al. 2009). Explosions from lava emission sites were phreatomagmatic, involving molten lava released from the intrusion and groundwater or the hydrothermal system. Other explosions were phreatic, involving hot wall rock and groundwater or the hydrothermal system. Intracaldera landslides accompanied caldera collapse from the beginning on 5 April to the end on 19 April.

Intracaldera lava emissions and collapse-related explosions both increased in frequency and size during 6 and 7 April, after the main caldera collapse on 5 April. The large collapse $\left(\sim 91 \times 10^{6} \mathrm{~m}^{3}\right.$; Derrien et al. 2020) on 5 April was a prerequisite for the intracaldera lava emissions, tively dilute ash plumes were generated by phreatic explosions involving hot wall rock and the shallow hydrothermal system and/or groundwater. These explosions were preceded by increases in steam emissions from fumaroles focussed along fractures close to the explosion site ("s" pattern). c Dust plumes accompanied landslides into the caldera and were immediately dispersed by wind. Cartoons are not to scale

exposing a previously concealed intrusion, and for the collapse-related explosions, allowing the direct interaction of shallow groundwater or the hydrothermal system with magma.

Caldera collapse followed about three days of fountaining and lava effusion at the Piton Tremblet vent on the eastern flank of Piton de la Fournaise. These eruptions must have drained the summit magma reservoir, leading to caldera collapse, but did not affect the intrusion that had been emplaced the week before. It remains correct that the Piton de la Fournaise caldera collapse was a response to withdrawal of magma from the summit reservoir; however, not all of the summit magma reservoirs were drained. This complexity in magma storage at Piton de la Fournaise permitted the coincidence of magma withdrawal, caldera collapse, intracaldera lava emissions and intracaldera phreatomagmatic explosions. Our analysis of the 2007 Piton de la Fournaise caldera collapse extends understanding of basaltic caldera collapse and related hazards.

Supplementary Information The online version contains supplementary material available at https://doi.org/10.1007/s00445-022-01528-w. 
Acknowledgements This research formed part of the $\mathrm{PhD}$ thesis of DV, funded by a University of Tasmania Graduate Research Scholarship. The Piton de la Fournaise Volcanological Observatory and Institut de Physique du Globe de Paris provided full logistical support during fieldwork on La Réunion, assisted with access to the OVPF data base and contributed to the cost of thin sections. We thank Laurent Michon and Aline Peltier for comments on an earlier version of the manuscript. Critical reviews of the submitted manuscript by Matt Patrick, an anonymous reviewer and BV Editors, Andrew Harris and Julia Eychenne, are greatly appreciated.

Funding Open Access funding enabled and organized by CAUL and its Member Institutions.

Open Access This article is licensed under a Creative Commons Attribution 4.0 International License, which permits use, sharing, adaptation, distribution and reproduction in any medium or format, as long as you give appropriate credit to the original author(s) and the source, provide a link to the Creative Commons licence, and indicate if changes were made. The images or other third party material in this article are included in the article's Creative Commons licence, unless indicated otherwise in a credit line to the material. If material is not included in the article's Creative Commons licence and your intended use is not permitted by statutory regulation or exceeds the permitted use, you will need to obtain permission directly from the copyright holder. To view a copy of this licence, visit http://creativecommons.org/licenses/by/4.0/.

\section{References}

Anderson KR, Johanson IA, Patrick MR, Gu M, Segall P, Poland MP, Montgomery-Brown EK, Miklius A (2019) Magma reservoir failure and the onset of caldera collapse at Kîlauea Volcano in 2018. Science 366:1214

Bachèlery P, Mairine P (1990) Evolution volcano-structurale du Piton de La Fournaise depuis 0.53 Ma. In: Lénat JF (Ed) Le volcanisme de La Réunion. Centre de Recherches Volcanologiques, ClermontFerrand, pp 213-242

Derrien A, Villeneuve N, Peltier A (2015) Retrieving 65 years of volcano summit deformation from multi-temporal Structure-fromMotion: the case of Piton de la Fournaise (La Réunion Island). Geophys Res Lett 42:L064820

Derrien A, Villeneuve N, Michon L (2019) Multi-temporal airborne structure-from-motion on caldera rim: Hazard, visitor exposure and origins of instabilities at Piton de la Fournaise. Prog Phys Geogr 43(2): 193-214

Derrien A, Peltier A, Villeneuve N, Staudacher T (2020) The 2007 caldera collapse at Piton de la Fournaise: new insights from multitemporal structure-from-motion. Volcanica 3(1):55-65

Di Muro A, Metrich N, Vergani D, Rosi M, Armienti P, Fougeroux T, Deloule E, Arienzo I, Civetta L (2014) The shallow plumbing system of Piton de la Fournaise volcano (La Réunion Island, Indian Ocean) revealed by the major 2007 caldera-forming eruption. J Petrol 55:1287-1315

Di Muro A, Métrich N, Allard P, Aiuppa A, Burton M, Galle B, Staudacher T (2016) Magma degassing at Piton de la Fournaise volcano. In: Bachelery P, Lenat JF, Di Muro A, Michon L (eds) Active Volcanoes of the Southwest Indian Ocean, Springer, pp 203-222

Duputel Z, Rivera, L (2019) The 2007 caldera collapse of Piton de la Fournaise volcano: source process from very-long-period seismic signals. Earth Planet Sci Lett 527:115786

Duputel Z, Lengliné O, Ferrazzin V (2019) Constraining spatiotemporal characteristics of magma migration at Piton de la
Fournaise volcano from pre-eruptive seismicity. Geophys Res Lett 46:119-127

Fontaine FR, Roult G, Michon L, Barruol G, Di Muro A (2014) The 2007 eruptions and caldera collapse of the Piton de la Fournaise volcano (La Réunion Island) from tilt analysis at a single very broadband seismic station. Geophys Res Lett 41(8):2803-2811

Fontaine FR, Roult G, Hejrani B, Michon L, Ferrazzini V, Barruol G, Tkalčić H, Di Muro A, Peltier A, Reymond D, Staudacher T, Massin F (2019) Very- and ultra-long-period seismic signals prior to and during caldera formation on La Réunion Island. Nature Communications Scientific Reports 9:8068

Froger JL, Cayol V, Famin V (2016) The March-April 2007 eruptions of Piton de la Fournaise as recorded by interferometric data. In: Bachèlery P, Lénat JF, Di Muro A, Michon L (eds) Active Volcanoes of the Southwest Indian Ocean: Piton de la Fournaise and Karthala. Springer-Verlag, Berlin Heidelberg, pp 271-286

Gallart J, Driad L, Charvis P, Sapin M, Hirn A, Diaz J, de Voogd B, Sachpazi M (1999) Perturbation to the lithosphere along the hotspot track of La Réunion from an offshore-onshore seismic transect. J Geophys Res 104:2895-2908

Geshi N, Oikawa T (2008) Phreatomagmatic eruptions associated with the caldera collapse during the Miyakejima 2000 eruption, Japan. J Volcanol Geotherm Res 176:457-468

Geshi N, Shimano T, Chiba T, Nakada S (2002) Caldera collapse during the 2000 eruption of Miyakejima volcano, Japan. Bull Volcanol 64:55-68

Gillot PY, Nativel P (1989) Eruption history of the Piton de la Fournaise volcano, Réunion Island, Indian Ocean. J Volcanol Geotherm Res 36:53-55

Gillot PY, Lefèvre JC, Nativel P (1994) Model for the structural evolution of the volcanoes of Réunion Island. Earth Planet Sci Lett 122:291-302

Hibert C, Mangeneya A, Grandjeanb G, Peltier A, DiMuroc A, Shapiroa N, Ferrazzini V, Boissier P, Duranda V, Kowalski P (2017) Spatio-temporal evolution of rockfall activity from 2007 to 2011 at the Piton de la Fournaise volcano inferred from seismic data. J Volcanol Geotherm Res 333-334:36-52

Lénat JF, Bachèlery P, Peltier A (2012a) The interplay between collapse structures, hydrothermal systems, and magma intrusions: the case of the central area of Piton de la Fournaise volcano. Bull Volcanol 74:407-421

Lénat JF, Bachèlery P, Merle O (2012b) Anatomy of Piton de la Fournaise volcano (La Réunion, Indian Ocean). Bull Volcanol 74:1946-1961

Lénat JF (2016) Construction of La Réunion. In: Bachèlery P, Lénat JF, Di Muro A, Michon L (eds) Active Volcanoes of the Southwest Indian Ocean: Piton de la Fournaise and Karthala. SpringerVerlag, Berlin Heidelberg, pp 31-44

Massin F, Ferrazzini V, Bachèlery P, Nercessian A, Duputel Z, Staudacher T (2011) Structures and evolution of the plumbing system of Piton de la Fournaise volcano inferred from clustering of 2007 eruptive cycle seismicity. J Volcanol Geotherm Res 202:96-106

Mauri G, Saracco G, Labazuy P, Williams-Jones G (2018) Correlating hydrothermal system dynamics and eruptive activity-a casestudy of Piton de la Fournaise volcano, La Réunion. J Volcanol Geotherm Res 363:23-39

Michon L, Staudacher T, Ferrazzini V, Bachelery P, Marti J (2007) April 2007 collapse of Piton de la Fournaise: a new example of caldera formation. Geophys Res Lett 34:L21301

Michon L, Villeneuve N, Catry T, Merle O (2009) How summit calderas collapse on basaltic volcanoes: new insights from the April 2007 caldera collapse of Piton de la Fournaise volcano. J Volcanol Geotherm Res 184:138-151

Michon L, Massin F, Famin V, Ferrazzini V, Roult G (2011) Basaltic calderas: collapse dynamics, edifice deformation, and variations of magma withdrawal. J Geophys Res 116(B3):B03209 
Michon L, Di Muro A, Villeneuve N, Saint-Marc C, Fadda P, Manta F (2013) Explosive activity of the summit cone of Piton de la Fournaise volcano (La Réunion island): a historical and geological review. J Volcanol Geotherm Res 264:117-133

Michon L, Ferrazzini V, Di Muro A (2016) Magma paths at Piton de la Fournaise volcano. In: Bachèlery P, Lénat JF, Di Muro A, Michon L (eds) Active Volcanoes of the Southwest Indian Ocean: Piton de la Fournaise and Karthala. Springer-Verlag, Berlin Heidelberg, pp 91-106

Neal C, Brantley S and 54 others (2019) The 2018 rift eruption and summit collapse of Kīlauea Volcano. Science 363:367-374

Nercessian A, Hirn A, Lépine JC, Sapin M (1996) Internal structure of Piton de la Fournaise volcano from seismic wave propagation and earthquake distribution. J Volcanol Geotherm Res 70(3-4):123-143

Ort MH, Di Muro A, Michon L, Bachèlery P (2016) Explosive eruptions from the interaction of magmatic and hydrothermal systems during flank extension: the Bellecombe Tephra of Piton de La Fournaise (La Réunion Island). Bull Volcanol 78(1):5

Peltier A, Famin V, Bachèlery P, Cayol V, Fukushima Y, Staudacher T (2008) Cyclic magma storages and transfers at Piton de la Fournaise volcano (La Réunion hotspot) inferred from deformation and geochemical data. Earth Planet Sci Lett 270:180-188

Peltier A, Bachélery P, Staudacher T (2009a) Magma transport and storage at Piton de la Fournaise volcano (La Réunion) between 1972 and 2007: a review of geophysical and geochemical data. J Volcanol Geotherm Res 184:93-108

Peltier A, Staudacher T, Bachèlery P, Cayol V (2009b) Formation of the April 2007 caldera collapse at Piton de la Fournaise volcano: insights from GPS data. J Volcanol Geotherm Res 184:152-163

Peltier A, Massin F, Bachèlery P, Finizola A (2012) Internal structure and building of basaltic shield volcanoes: the example of Piton de la Fournaise terminal cone (la Réunion). Bull Volcanol 74:1881-1897

Prôno E, Battaglia J, Monteiller V, Got JL, Ferrazzini V (2009) P-wave velocity structure of Piton de la Fournaise volcano deduced from seismic data recorded between 1996 and 1999. J Volcanol Geotherm Res 184(1-2):49-62

Roult G, Peltier A, Staudacher T, Ferrazzini V, Taisne B, Di Muro A, OVPF team, (2012) A comprehensive classification of the Piton de la Fournaise eruptions (La Réunion Island) spanning the 19862010 period. Search for eruption precursors from the broad-band
GEOSCOPE RER station analysis and interpretation in terms of volcanic processes. J Volcanol Geotherm Res 241:78-104

Simkin T, Howard KA (1970) Caldera collapse in the Galapagos Islands, 1968: the largest known collapse since 1912 followed a flank eruption and explosive volcanism within the caldera. Science 169 (3944):429-437

Staudacher T (2010) Field observations of the 2008 summit eruption at Piton de la Fournaise (Ile de La Réunion) and implications for the 2007 Dolomieu collapse. J Volcanol Geotherm Res 191(1):60-68

Staudacher T, Cheminée A (2002) La Réunion, Ile volcanique située sur un point chaud. OVPF/IPGP, La Réunion, pp 1-24

Staudacher T, Ferrazzini V, Peltier A, Kowalski P, Boissier P, Catherine P, Lauret F, Massin F (2009) The April 2007 eruption and the Dolomieu crater collapse, two major events at Piton de la Fournaise (La Réunion Island, Indian Ocean). J Volcanol Geotherm Res 184:126-137

Staudacher T, Peltier A, Ferrazzini V, Di Muro A, Boissier P, Catherine P, Kowalski P, Lauret F, Lebreton J (2016) Fifteen years of intense eruptive activity (1998-2013) at Piton de la Fournaise Volcano: a review. In: Bachèlery P, Lénat JF, Di Muro A, Michon L (eds) Active Volcanoes of the Southwest Indian Ocean: Piton de la Fournaise and Karthala. Springer-Verlag, Berlin Heidelberg, pp 139-170

Terry RD, Chilingar GV (1955) Summary of "Concerning some additional aids in studying sedimentary formations," by MS Shvetsov. J Sediment Pet 25:229-234

Thivet S, Gurioli L, Di Muro A, Eychenne J, Besson P, Nedelec JM (2020) Variability of ash deposits at Piton de la Fournaise (La Réunion Island): insights into fragmentation processes at basaltic shield volcanoes. Bull Volcanol 82:63

Urai M, Geshi N, Staudacher T (2007) Size and volume evaluation of the caldera collapse on Piton de la Fournaise volcano during the April 2007 eruption using ASTER stereo imagery. Geophys Res Lett 34 (L22318)

Vergani D (2018) The 2007 explosive activity at Piton de la Fournaise Volcano (La Réunion Island): constraints on the eruptive processes by the volcanological study of the erupted deposits. PhD thesis, University of Tasmania (unpublished), $193 \mathrm{pp}$

White JDL, Houghton BF (2006) Primary volcaniclastic rocks. Geology 34(8):677-680 